\title{
EFFECTS OF DRUGS
}

ON CELLULAR CONTROL MECHANISMS 


\section{BIOLOGICAL COUNCIL}

The Co-ordinating Committee for Symposia

on Drug Action

A Symposium on

\section{EFFECTS OF DRUGS \\ ON CELLULAR CONTROL MECHANISMS}

Edited by

B. R. RABIN

Department of Biochemistry,

University College,

London

and

\section{R. B. FREEDMAN}

Biology Laboratory,

University of Kent

at Canterbury 
ISBN 978-1-349-01323-4 ISBN 978-1-349-01321-0 (eBook)

DOI 10.1007/978-1-349-01321-0

(C) Institute of Biology Endowment Fund 1971

Softcover reprint of the hardcover 1st edition 1971 978-0-333-13147-3

All rights reserved. No part of this publication may be reproduced or transmitted, in any form or by any means, without permission

First published 1971

THE MACMILLAN PRESS LTD

London and Basingstoke

Associated companies in New York Melbourne

Toronto Dublin Johannesburg and Madras

SBN 333131479 


\section{PREFACE}

The Biological Council sponsors annually a Symposium on drug action and this book records the proceedings of the 1971 Symposium, the organisation of which was made possible by generous help from the Wellcome Trust and CIBA Foundation.

The first day of the Symposium was devoted to a discussion of the Role of Steroid Hormones in Control Processes under the chairmanships of J. R. Tata and T. F. Slater. The coverage is very wide and ranges from physicochemical studies of the interaction of steroid hormones with macromolecules and membranes to the role of steroid hormones in development and gene expression. The second day of the Symposium was devoted to Cyclic AMP. The morning session, chaired by B. R. Rabin, covered some basic biochemical aspects and the afternoon session, chaired by H. O. Schild, covered material of more direct pharmacological interest. Many of the papers on both days provoked lively discussion, much of which is recorded in this book. The meeting was truly interdisciplinary and this book shows very clearly how thoroughly inter-related pharmacology and biochemistry have become. It is our hope that this book will encourage others to cross the constraining boundaries of their individual specialisms.

B.R.R.

R.B.F. 


\title{
SYMPOSIUM ORGANISATION
}

\author{
BIOLOGICAL COUNCIL
}

Co-ordinating Committee for Symposia on Drug Action

\section{EFFECTS OF DRUGS ON CELLULAR CONTROL MECHANISMS}

Report of a Symposium held on 29 and 30 MARCH 1971

in

London

at The Middlesex Hospital Medical School

\author{
Sponsored by \\ British Pharmacological Society \\ and \\ Biochemical Society \\ British Society for Cell Biology \\ British Society for Immunology \\ Nutrition Society \\ Pharmaceutical Society of Great Britain \\ Physiological Society \\ Royal Society of Medicine \\ Society for Drug Research \\ Society for Endocrinology \\ Society for Experimental Biology
}

Organised by a Symposium Committee consisting of:

B. R. Rabin (Chairman and Hon. Secretary)

D. H. Jenkinson

A. Korner

J. L. Mongar

T. F. Slater 


\section{CONTENTS}

List of Contributors

Page

ix

Session I: Role of Steroid Hormones in Control Processes

'Pleiotypic' and 'specific' hormonal control of gene expression in mammalian cells G. M. TOMK IN S

Control of oestrogen action by specific oestrogen-protein interaction R. J. B. KING

The effects of steroid hormones and carcinogens on the interaction of membranes with polysomes B. R. RABIN, CAROL A. BLYTH, DELMA DOHERTY, R. B. FREEDMAN, ANNE ROOBOL, G. SUNSHINE and D. J. WILLIAMS

The control of lysosomal enzyme synthesis and effects of steroids A.C. ALLISON and P. DAVIES

The effects of drugs and steroid hormones on the enzymes of the endoplasmic reticulum

D. V. PARKE

Corticosteroid binding proteins of liver cytosol and interactions with carcinogens G. LITW ACK, K. S. MOREY and B. KETTERER

Steroids and the development of mammary epithelial cells Y. J. TOPPER and T. OKA

\section{Session II: Role of Cyclic AMP in Control Processes}

Basic biochemistry and control of production of cyclic AMP K. J. HITTELMAN and R. W. BUTCHER 
The effect of cyclic AMP on membrane-bound protein kinases and phosphatases in mammalian tissues R. RODNIGHT and M. WELLER

Effect of cyclic AMP on gene expression in E. coli D. SCHLESSINGER, Y. OHNISHI, M. KUWANO and L. SILENGO

Interaction of prostaglandins and cyclic AMP P. W . RAMWELL and I. RABINOWITZ

Platelet aggregation and cyclic AMP G. V. R. BOR N

Cyclic AMP and the anaphylactic reaction E. S. K. A SSEM 259

Cyclic AMP and tissues of the brain H. McILW AIN 281 


\section{LIST OF CONTRIBUTORS}

Dr A. C. Allison, Clinical Research Centre, Watford Road, Harrow, Middx.

Dr E. S. K. Assem, Department of Pharmacology, University College London, WC1E 6BT

Mr T. Atkins, Department of Biological Sciences, University of Aston in Birmingham, Birmingham

Dr A. W. Bennett, Department of Surgery, King's College Hospital Medical School, London S.E.5

Dr Carol A. Blyth, Department of Biochemistry, University College London, Gower Street, London WC1E 6BT

Professor G. V. R. Born, Department of Pharmacology, Royal College of Surgeons, Lincoln's Inn Fields, London W.C.2

Dr R. W. Butcher, University of Massachusetts Medical School, Department of Biochemistry, 419 Belmont Street, Worcester 01604, Mass., U.S.A.

Dr M. J. Clemens, National Institute of Medical Research, The Ridgeway, Mill Hill, London NW7 1 AA

Dr N. R. Cohen, The Open University, Walton Hall, Milton Keynes, Bletchley, Bucks.

Dr B. M. Cox, Department of Pharmacology, Chelsea College of Science and Technology, Manresa Road, London S.W.3

Dr P. Davies, Clinical Research Centre, Watford Road, Harrow, Middx.

Dr M. Delma Doherty, Biochemistry Department, University of Queensland, St Lucia, Brisbane 4067, Queensland, Australia

Dr I. R. Falconer, Department of Applied Biochemistry and Nutrition, University of Nottingham

Dr I. A. Forsyth, National Institute for Research in Dairying, Shinfield, Reading, Berks.

Dr R. B. Freedman, Biology Laboratory, University of Kent at Canterbury, Canterbury, Kent

Dr J. D. P. Graham, Department of Pharmacology, Welsh National School of Medicine, Heath Park, Cardiff CF4 4XW

Dr D. G Grahame-Smith, Medical Unit, St Mary's Hospital Medical School, Lcidon W.2

Professor J. K. Grant, Department of Steroid Biochemistry, University of Glasgow, Glasgow Royal Infirmary, Glasgow C.4

Dr R. J. Haslam, I.C.I. Ltd (Pharmaceuticals Division), Alderley Park, Macclesfield, Cheshire

Professor P. J. Heald, Department of Biochemistry, University of Strathclyde, Glasgow C.2

Dr K. J. Hittelman, Department of Biochemistry, School of Medicine, University of Massachusetts, Worcester, Mass., U.S.A.

B. Hughes, Beecham Research Laboratory, The Pinnacles, Harlow, Essex

Dr K. D. Jaitly, Royal Netherlands Fermentation Industries Ltd., Delft, Holland Dr J. S. Jenkins, St George's Hospital, London S.W.1 
Dr Brian Ketterer, Courtauld Institute of Biochemistry, Middlesex Hospital Medical School, London W.1

Dr R. J. B. King, Department of Hormone Biochemistry, Imperial Cancer Research Fund, Lincoln's Inn Fields, London WC2A 3PX

Professor H. W. Kosterlitz, Department of Pharmacology, University Medical Buildings, Foresterhill, Aberdeen AB9 22D

Dr Ilse Lasnitzki, Strangeways Laboratory, Cambridge

Professor G. Litwack, Department of Biochemistry, Fels Research Institute, Temple University, Health Sciences Center, School of Medicine, Philadelphia, Penn. 19140, U.S.A.

Professor H. McIlwain, Department of Biochemistry, Institute of Psychiatry, De Crespigny Park, London S.E.5

Dr W. J. Marshall, King's College Hospital Medical School, Department of Chemical Pathology, London S.E.5

Dr J. Matthews, Chemical Sciences Research Department, Boots Pure Drug Co., Pennyfoot Street, Nottingham

Dr R. H. Mitchell, Department of Biochemistry, University of Birmingham, Birmingham

Dr D. Monard, Friedrich Miescher Institute, P.O. Box 273, CH-4002 Basel, Switzerland

Dr K. S. Morey, California State Polytechnic College, San Luis Obispo, California, U.S.A.

Dr R. Neher, Friedrich Miescher Institute, P.O. Box 273, CH-4002 Basel, Switzerland

Dr T. Oka, Department of Health, Education and Welfare, Public Health Service, National Institute of Health, Bethesda, Maryland 20014, U.S.A.

Professor J. A. Olson, Department of Biology, Middlesex Hospital Medical School, Cleveland Street, London W.1

Professor D. V. Parke, Biochemistry Department, University of Surrey, Guildford, Surrey

Professor V. R. Pickles, Physiology Department, University College, Cardiff

Dr G. Powis, Department of Pharmacology, Glasgow University, Glasgow W.2

Professor B. R. Rabin, Department of Biochemistry, University College London, Gower Street, London WC1E 6BT

Dr I. Rabinowitz, Alza Corporation, 950 Page Hill Road, Palo Alto, California 94304, U.S.A.

Dr P. Ramwell, Alza Corporation, 950 Page Hill Road, Palo Alto, California 94304, U.S.A.

Dr R. Rodnight, Department of Biochemistry, Institute of Psychiatry, De Crespigny Park, London S.E.5

Dr Anne Roobol, Tropical Metabolism Research Unit, University of the West Indies, Mona, Kingston 7, Jamaica

Professor H. O. Schild, F.R.S., Department of Pharmacology, University College London, Gower Street, London WC1E 6BT

Dr D. Schlessinger, Washington University School of Medicine, Department of Microbiology, 4550 Scott Avenue, St Louis, Missouri 63110, U.S.A.

Dr J. G. Schofield, Biochemistry Department, Medical School, University Walk, Bristol

Professor T. F. Slater, Department of Biology, Brunel University, Kempton Lane, Hillingdon, Uxbridge, Middx.

Mr H. Smith, Beecham Research Labs, Brockham Park, Betchworth, Surrey 
Mr J. B. Smith, Department of Pharmacology, Royal College of Surgeons, Lincoln's Inn Fields, London W.C.2

Dr A. R. Somerville, I.C.I. Ltd. (Pharmaceutical Division), Alderley Park, Macclesfield, Cheshire

Dr M. Stockham, Allen \& Hanbury's Ltd., Ware, Herts.

Mr F. M. Sullivan, Department of Pharmacology, Guy's Hospital Medical School, London S.E.1

Mr G. Sunshine, Department of Biochemistry, University College London, Gower Street, London WC1E 6BT

Dr D. Szollosi, Animal Research Station, Huntingdon Road, Cambridge

Dr J. R. Tata, National Institute of Medical Research, Mill Hill, London NW7 $1 \mathrm{AA}$

Dr G. M. Tomkins, Department of Biochemistry, University of California Medical Center, San Francisco, California, U.S.A.

Dr Yale J. J. Topper, Department of Health, Education and Welfare, Public Health Service, National Institute of Health, Bethesda, Maryland 20014, U.S.A.

Dr M. Weller, Department of Biochemistry, Institute of Psychiatry, De Crespigny Park, London S.E.5

Dr D. J. Williams, Department of Biochemistry, University College London, Gower Street, London WC1E 6BT

Dr D. C. Wilton, Department of Physiology and Biochemistry, University of Southampton 